\title{
分子ディスプレイによる創薬基盤技術の展開
}

\author{
芝崎誠司
}

\section{Development of Platform Technology Using Molecular Display}

\author{
Seiji SHIBASAKI \\ Department of Pharmacy, School of Pharmacy, Hyogo University of Health Sciences, \\ 1-3-6 Minatojima, Chuo-ku, Kobe 650-8530, Japan
}

(Received June 17, 2009)

\begin{abstract}
Techniques for immobilizing proteins on surface of virus or microorganisms, namely molecular display technologies, have played important roles in helping the elucidation of protein-protein interactions in cells and to develop research on drug discovery. Phage display system is well-established and sophisticated; consequently, bioactive lowmolecular-weight ligands and proteins significant in pharmaceutical industry have been found. In addition to the development of novel functional proteins by phage display using results from experiments in genomics and proteomics, ribosome display or yeast display systems have been developed as complementary methods. We can select the appropriate method on the basis of the objective. Molecular display using yeast has advantages in production of desired proteins from combinatorial library by flow cytometry. Firstly, principle, development procedure, and latest research in this field are introduced. Thereafter, results of molecular display using yeast for antibodies and their related proteins are presented. Furthermore, display of receptor coupled with intracellular signal transduction - a novel type of molecular display on yeast cell surface - has been created in recent years. The role and potential of molecular display technologies employing yeast cells in drug discovery are discussed.
\end{abstract}

Key words — molecular display; yeast; Protein A; antibody; receptor

\section{1. はじめに}

ウイルスや微生物の表層にタンパク質分子やペプ チド分子を提示させる分子ディスプレイ法，特にフ アージディスプレイは種々の生命現象を支配する細 胞内外での分子間相互作用の解明や，創薬研究の一 端を担ってきた. ${ }^{1,2)}$ 現在，ファージディスプレイを 駆使するための知見は数多く蓄積され，生理活性を 有する分子リガンドや医薬として機能し得るタンパ ク質・ペプチド分子が取得されるに至っている. ${ }^{3)}$

今後ゲノミクスやプロテオミクスにより得られた 情報は，ファージディスプレイを用いた新機能分子 の創出を加速するものと思われるが，後発のリボ ソームディスプレイや酵母ディスプレイなどによ り，ファージを用いる系では対応できなかった分子 ディスプレイライブラリーの構築や選択法が出現

兵庫医療大学薬学部医療薬学科（T 650-8530 神戸市中 央区港島 1-3-6)

e-mail: seiji@ huhs.ac.jp

本総説は, 日本薬学会第 129 年会シンポジウム S05 で 発表したものを中心に記述したものである.
し, 用途に応じた使い分けも次第に明確になり, 1) それぞれが補完的な技術要素として発展しつつあ る. なかでも酵母分子ディスプレイでは，フローサ イトメーター等ハイスループットなスクリーニング システムを用いることで，ライブラリ一細胞集団か ら，望む機能を有する分子や細胞を濃縮，若しくは 単離できるという利点がある.

本稿ではまず，分子ディスプレイの全体像を概観 し，酵母分子ディスプレイ法の原理，ならびに研究 の最前線を解説する。特に創薬と関連が深い抗体や 抗体関連分子のディスプレイについて紹介する。 ま た，近年では分子の細胞表層固定化技術に加え，受 容体タンパク質をディスプレイする技術も生まれる など，細胞内情報伝達系と共役させた次世代型の分 子ディスプレイ法についても解説し，これらの創薬 基盤技術としての展望を述べる.

\section{2. 分子ディスプレイの概要}

次世代シーケンサーに代表されるように，多くの 生物のゲノム情報の解析はかつてない速度で進み, これに伴いゲノムにコードされるタンパク質の機能 
解析は新たなる局面を迎えている。これまで，生化 学, 分子生物学的研究においては, タンパク質の発 現系として主に，細胞内発現と細胞外分泌発現の 2 つの系が利用されてきた．現在，プロテオミクのよ うにタンパク質を網羅的に機能・構造解析する場合 においても，基本的にはこれらのように宿主細胞の 転写翻訳システムに依存している場合が多数であ る。しかし，細胞内発現系では，タンパク質の細胞 内での蓄積による毒性や，不活性なインクルージョ ンボディーとなることが多く，うまく発現できた場 合でも細胞破砕や精製プロセスが必要となる，イン クルージョンボディーの解決には，これらの操作に リフォールディングのプロセスが別途必要となる。 また，細胞外分泌発現系を用いた場合は，タンパク 質分子の濃縮操作が必要であり，プロテアーゼなど の酵素による分解を阻害する必要が生じる。そこ で，細胞の転写翻訳系を用いつつも，これら両者の 問題の解決に向けた新しい発現系として「分子ディ スプレイ法」が開発されている.

分子ディスプレイの中で最も歴史が長いファージ ディスプレイは，Smith らにより最初に報告2)され て四半世紀を迎える現在でも，多くの研究者に利用 されており，相互作用タンパク質の探索やアフィニ ティーリガンド分子の選択法として，そのプロト コールが確立している。一方，大腸菌や乳酸菌など のバクテリア等においても，ファージディスプレイ ほど一般的とは言えないが，様々な工夫を導入した 分子ディスプレイ法が報告されている．大腸菌 $E s-$ cherichia coli の系では外膜タンパク質の $\mathrm{LumO}^{4)}$ や OmpA, 5) 乳酸菌6) Lactobacillus や Lactococcus では表層タンパク質の Proteinase P をアンカーと して細胞最外殼層に目的タンパク質をディスプレイ できる。また，リボソームディスプレイは無細胞抽 出系を用いたシステムであり，タンパク質とそれを コードする RNA をリボソームを介して連結させ る。終止コドンを欠失させ，DNA スペーサーを付 加した mRNA を用いてタンパク質合成を行わせる ことで，タンパク質分子をリボソームにディスプレ イするという仕組みである.

上記のようなディスプレイ系に対して，酵母ディ スプレイ系は宿主細胞が真核生物由来タンパク質の 発現に有利であることに加え，フローサイトメータ によるソーティングが可能であるという長所を備え
ている.さらに，ハイスループットなスクリーニン グ系で選択されたクローンを用いて，直接目的分子 の増幅や生産系へ持ち込むことが可能など大きな利 点を持つ.これまでいくつかの種類の酵母を用いた 分子ディスプレイが報告されているが，次項からは 主に，出芽酵母 Saccharomyces cerevisiae を宿主と

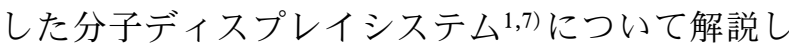
たい.

\section{3. 酵母分子ディスプレイの原理}

まず，酵母ディスプレイ系においてタンパク質提 示の足場となる S. cerevisiae の細胞壁の構造と, 夕 ンパク質が表層へ到達するまでのメカニズムについ て解説する．S. cerevisiae の最外殼に位置する細胞 壁は， $\beta$-1,3-と $\beta$-1,6-グルカンを骨格とし， 2 つの タイプのマンナンタンパク質を含んでいる（Fig. 1)。マンナンタンパク質の 1 つは非共有結合により ほかの細胞壁成分に結合しており，熱 SDSにより 抽出されるものであり，もう一方は共有結合により 結合していて酵素グルカナーゼにより抽出されるも のである．酵母分子ディスプレイでは，目的タンパ ク質のアンカーに後者の細胞壁タンパク質がしばし

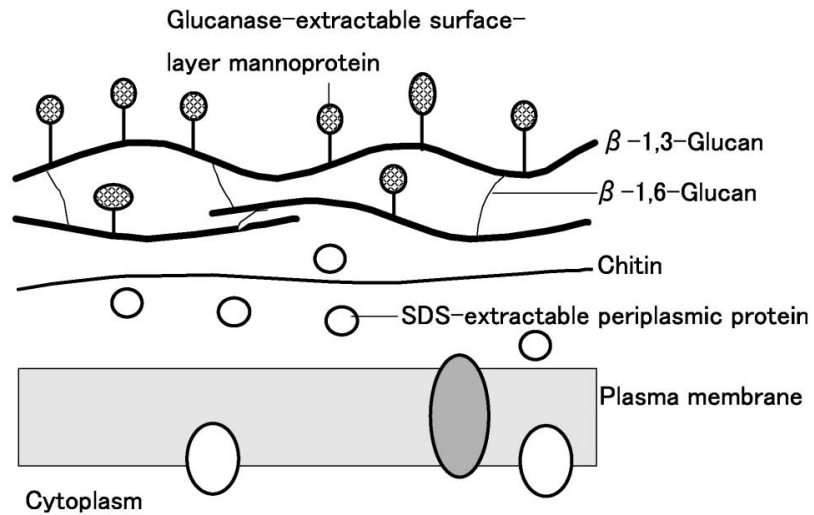

Fig. 1. Structure of Yeast Cell Wall

Most-outer surface of yeast cell is surrounded by $\beta$-1,3- and $\beta$-1,6-glucan. Glucanase-extractable surface layer mannnoproteins are covalently linked to these components.

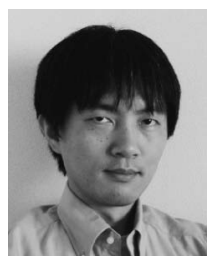

芝崎誠司
兵庫医療大学薬学部・准教授. 2001 年 京都大学大学院工学研究科合成・生物 化学専攻博士後期課程修了. 工学博士. 2001 年神戸市立工業高等専門学校助手, 2002 年同講師, 2005 年同助教授. 2004 年スウェーデン王立工科大学客員研究 員. 2007 年より現職. 現在の研究テー マ：酵母分子ディスプレイによる新規 機能分子並びに新規細胞の創出. 
ば用いられ，例えば，a-アグルチニン，Flo1 ある いは Cwp1 などによる表層ディスプレイが報告され ている．筆者らが行ってきた性凝集素タンパク質 $\alpha$ アグルチニンを活用した酵母分子ディスプレイシス テムの原理を以下に示す.

$\alpha$-アグルチニンの分子構造は 3 つに区分すること ができ，分泌シグナル，機能ドメイン，細胞壁ドメ インより構成されている。 また細胞壁ドメインは, セリンとスレオニンに富む 320 アミノ酸残基と，こ の C 末端に GPI（Glycosylphosphatidylinositol）ア ンカー付着シグナルが存在するという特徵を持って いる。このような構造を有する $\alpha$-アグルチニン の，分泌シグナルと機能ドメインに手を加えること で，目的とするタンパク質を細胞表層へディスプレ イすることができる．ここで鍵となるのが，分泌シ グナルの配置と，遺伝子発現におけるプロモーター の選択である．Fig. 2(A)のように，目的タンパク 質をコードする遺伝子の $5^{\prime}$ 末側に分泌シグナル， $3^{\prime}$ 末側に $\alpha$-アグルチニン細胞壁ドメインの遺伝子配 列を融合させることで，Fig. 2 (B)のように，エキ ソサイトーシスにより融合タンパク質は細胞膜へ到 達することになる。GPI アンカーはPI-PLC (Phosphatidyl inositol-specific phospholiase C) の作 用で切断され，最終的に目的タンパク質は $\alpha$-アグ ルチニンを介して，細胞壁に固定化されることにな る. 分泌シグナルは， $\alpha$-アグルチニン由来のものを 用いてもよいが，酵母細胞内で機能するシグナルで あれば異種タンパク質のものでも適用することがで きる．実際，多くの酵母分子ディスプレイ系では，
糸状菌由来のグルコアミラーゼの分泌シグナル配列 が用いられている。また，プロモーターに関して は，構成発現型か，若しくは誘導発現型が適してい るのかを目的に応じて判断する必要がある．なる心゙ く多くのタンパク質をディスプレイし，提示した酵 素分子と宿主細胞の代謝系とを共役さるような，い わゆる細胞触媒として利用する場合は，培養初期か ら発現する解糖系のグリセルアルデヒド 3 リン酸デ ヒドロゲナーゼ $(G A P D H)$ のプロモーターのよう 構成発現型プロモーターが効果的であることが示さ れてきた。一方，外部環境に応答して蛍光タンパク 質の提示量を変化させ，宿主細胞を細胞センサーと して機能を賦与する場合は，それぞれの環境因子に 応答する誘導発現型プロモーターが適していると言 える. 8,9$)$

これまで，上記のシステムを用いてディスプレイ されたタンパク質分子には酵素分子が多く，これら の酵母細胞は様々な発酵プロセスにおいて，物質変 換に必須の代謝酵素群を包括する細胞触媒として活 用されてきた。このように異種酵素をディスプレイ することで, より付加価値の高い触媒能を酵母細胞 に賦与10)できるだけでなく，外部環境に応じて蛍光 タンパク質をディスプレイする細胞センサー8,9) や，重金属捕捉ペプチド11)やホルモン受容体 ${ }^{1)}$ のデ イスプレイによるバイオレメディエーションの吸着 担体として機能も見い出されている.

酵母分子ディスプレイ法の最大の利点は，培養に より細胞を繰り返し利用でき，遺伝子配列さえ入手 できれば，ほとんどのタンパク質やペプチドのディ
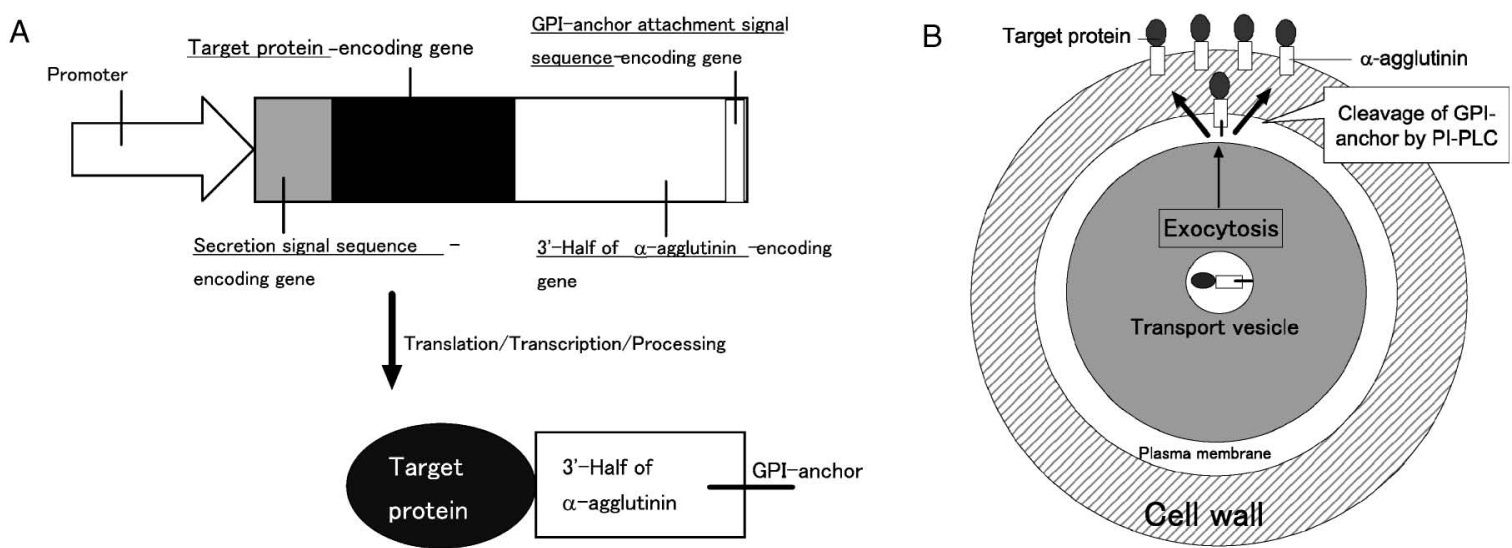

Fig. 2. Genetic Construction for Molecular Display and Transportation Mechanism

(A) A target protein-encoding gene is situated between secretion signal sequence- and $\alpha$-agglutinin-encoding genes. (B) Fusion protein of a target protein and $\alpha$-agglutinin is transported to cell surface via exocytosis. 
スプレイが可能であるということである，さらに， 酵素の熱あるいは $\mathrm{pH}$ に対する安定性向上にもつな がることが明らかとなっている. ${ }^{12)}$

\section{4. 創薬を志向した酵母分子ディスプレイの応用} 例

次に，薬学・創薬分野において活用が期待される 応用例について紹介したい,

まず 1 つ目の応用例として，抗体回収系が挙げら れる。一般的な生化学実験において IgG などの抗 体分子を精製する場合は，特異的な結合性を示す黄 色ブドウ球菌由来 Protetin A を，セファロースな ぞの担体に固定化したカラムを用いる． IgG は Fc 領域が Protein A と親和性を示すことが知られてい るが, Protein AのBドメインのコンビナトリアル 変異により創製された Z ドメインと特に高い親和 性を示すことが明らかとなっており, 3 ,7) Z ドメイン をコードする遺伝子は精製タグとして市販のべク ターにも組込まれている．生化学試薬など研究用抗 体に加え，医薬として期待される抗体，あるいはそ の候補分子を回収するシステムに応用できるツール が分子ディスプレイ法により開発された. ${ }^{13)}$

Z ドメインをタンデムに融合した ZZ ドメインを コードする遺伝子配列が，Fig. 2 と同じ要領で目的 タンパク質コード領域として配置され，マルチコ ピー型プラスミドにより作製された，ZZ ドメイン を細胞表層に最大限にディスプレイするための，プ ロモーター，ならびに細胞株の検討が行われた。こ れまでの研究より，酵母一細胞あたり， $10^{5}$ 分子の タンパク質，ペプチドがディスプレイできることが 明らかとなっている14)が，これまでは，細胞株とプ ロモーターの組合わせからの検討はほとんどなされ ていなかった。 そこで，分子ディスプレイ系に汎用 されてきた MT8-1に加え，W303-1a，BY4741， BY4742 株を用いて，GLA1（ガラクトース誘導性） プロモーター，UPR-ICL（イソクエン酸リアーゼ） プロモーター，GAPDH プロモーターによる ZZ ド メイン分子ディスプレイについて検討した. ここで UPR-ICL のみ Candida tropicalis より取得されて た異種プロモーターで，グルコースが枯渇した際に 転写を活性化する。 その結果，BY4742で GAL1 プ ロモーターを用いた場合に最も多くの ZZ ドメイン を細胞表層にディスプレイできたので，以降この分 子ディスプレイ系 BY4742: GUZZ 株が使用された。
次に，この BY4742: GUZZ 株を用いて，初期 $\mathrm{pH}$ などの最適培養条件について検討した。通常, 酵母の増殖用培地の初期 $\mathrm{pH}$ は 5-6 付近であり, 定 常期に入る頃には $\mathrm{pH}$ 2-3 まで低下し，細胞表層上 にディスプレイ分子された分子はこれらの培地と接 触しているため，酸による変性を受けることが懸念 される。そこで，BY4742: GUZZ 株において ZZ 発現を誘導するための培地であるガラクトース含有 合成培地（SDC-ura；カザミノ酸を含む）の培養開 始前の初期 $\mathrm{pH}$ を 5.6-8.0 に調整し，培養後 Alexa488 標識抗体と反応させ，細胞表層から得られる蛍 光強度を FACS で測定，比較した。その結果， $\mathrm{ZZ}$ ドメインの分子ディスプレイには宿主としては, BY4742 株を使用し，GAL1 プロモーターの制御下 で初期 pH 6.4 の SDC-ura 培地で培養した場合に, 活性を有した Z ドメインが最も多くディスプレイ され，抗体，並びに $\mathrm{Fc}$ 融合夕ンパク質の回収系と して利用できる可能性が示唆された.

次に, BY4742: GUZZ 株の表層に提示された ZZ ドメインにより，血清から $\operatorname{IgG}$ の精製が可能であ ることを確認した。さらに，酵母による抗体産生／ 回収モデル系として，酵母が分泌生産した Fc 融合 タンパク質を ZZ ドメインに結合させ，精製できる システムを考案した（Fig. 3)。まず，GFP-Fc 融合 タンパク質の分泌生産とその回収系の構築を試み た。当初，同一の細胞で GFP-Fc 分泌生産と, $\mathrm{ZZ}$ のディスプレイを行ったが，分子ディスプレイも GFP-Fc 分泌生産系と同一の分泌システムを利用し ているため，ディスプレイが十分に行われなかつ た。そこで， ZZドメインのディスプレイと，GFP$\mathrm{Fc}$ の生産は別々の細胞に行わせることでこの問題 を解決した。表層にディスプレイされた ZZ ドメイ ンで GFP-Fc が捕捉できたことは，FACS 並びに蛍 光顕微鏡で確認し，これらが酸による溶出，中和に より効果的に回収できることが明らかとなった。さ らに，GFP のようなレポータータンパク質に限ら ず，化学的活性を持つタンパク質についても適応可 能であることを示すために, Rhizopus oryzae 由来 のリパーゼ（ROL; Rhizopus oryzae lipase）を Fc と融合し，生産／回収系について検討した。ここで は，ROL の活性部位が $\mathrm{C}$ 末端側にあることを考慮 し，ROLの $\mathrm{N}$ 末端側に Fc が融合され，Fc-ROL 分泌発現プラスミド pEU-ROLF2 を酵母細胞に導 
A

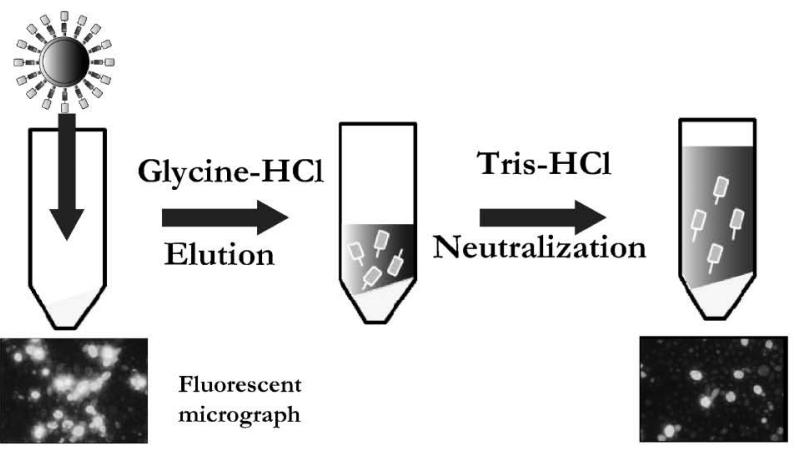

B Secretion of GFP-Fc

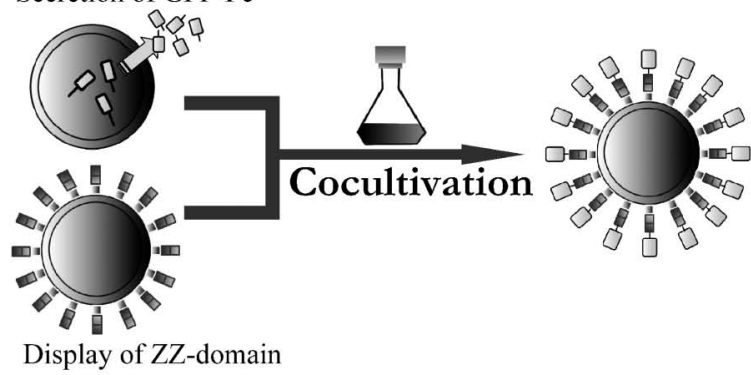

Fig. 3. Recovery System of Antibodies and Related Molecules Using ZZ-domain Displaying Yeast Cell

(A) GFP-Fc fusion proteins are bound on yeast cell surface displaying ZZ-domain and released by glycine-HCl. Neutralization by addition of Tris-HCl into the acidic supernatant must be performed immediately. (B) Synergistic production and recovery of secreted recombinant Fc-fusion proteins.

入して BY4742: ROLF2 株を得た. この株とBY4742: GUZZ の共培養により，GFP-Fc の場合と同様に Fc-ROL 融合タンパク質を回収したが，より高い回 収率を得るために，共培養を開始するタイミングに ついても検討した。その結果，ZZディスプレイ細 胞 BY4742: GUZZ を先行して培養し，6-18 時間の タイムラグを設けて Fc-ROL 分泌細胞を培養系へ 加えたときに，同時に共培養を開始したときの 1.5 倍の回収率が得られた。

2 つ目の応用例として，タンパク質分子ライブラ リーの構築が挙げられる。ゲノム情報が解明される につれ，それらの情報がコードするタンパク質分子 の機能解析が重要な課題となっている．特に創薬分 野における標的分子と相互作用するタンパク質分子 の網羅的な解析では，分子ディスプレイ法を活用し たタンパク質分子ライブラリーの構築が期待され る。酵母細胞を用いたライブラリーは，ファージや バクテリアの系では困難な，FACS やマイクロチャ ンバーアレイなどのハイスループットスクリーニン グシステムにて解析が可能であるという利点を生か すことができる．分子ディスプレイによる䤉母モデ ルライブラリーの構築と，そのスクリーニングの効 率を検討した結果を以下に述べる. ${ }^{15)}$

コンビナトリアルなタンパク質をディスプレイし た細胞集団の中から，目的分子と相互作用するク ローンとして，上述のProtein A と Fc の組み合わ せが，相互作用のモデルとして適用された。ただ し，この場合は先の抗体回収系とは異なり，Fc を 細胞表層にディスプレイし，Alexa488 標識した Protein A を相互作用の標的分子として結合させる ことになる。本系に関しては，プロモーターを検討
した結果，UPR-ICL が Fc ディスプレイ量に最も 優れていることが確認できたので，同プロモーター を用いて Fcディスプレイ細胞が調製されたＦc F゙ イスプレイ細胞と非ディスプレイ細胞数の比率を,

$1: 10^{4}, 1: 10^{5}$ ならびに $1: 10^{6}$ に設定し, Alexa488 標識 Protein A $(10 \mu \mathrm{g} / \mathrm{ml})$ と反応させた後, フロー サイトメーターにより，Fcディスプレイ細胞の回 収が試みられた。回収率は，ソーティングした細胞 集団の一部を SDC 平板培地にて生育させてコロ ニーをピックアップし， Fc をコードする遺伝子を PCR により同定することで算出している，第 1 サ

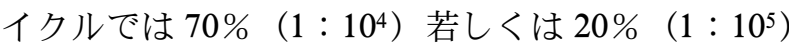
の回収率が得られたが，1：106の集団からはほと んど回収できなかった。しかし，第 1 サイクルで ソーティングした集団をもう一度同条件で培養し,

フローサイトメーターによる回収を繰り返したとこ ろ，第 2 サイクルでは $1: 10^{6}$ の集団を含むほかの 2 つのグループについても，ほぼ 100\%の回収率が 得られた。ここで用いたモデルライブラリーは，あ くまでも Fc-Protein A という既知の分子による相 互作用を利用したものであるが，フローサイトメー ターにより極微量のポジティブクローンを含む細胞 集団から，標的分子と結合したクローン分子をディ スプレイしている細胞を効果的に回収できることを 示唆している.

\section{5. 新しい酵母分子ディスプレイの可能性}

これまで，細胞内輸送システムと細胞壁アンカー による分子ディスプレイについて記述したが，ここ では同じ酵母細胞を用いた，新しい分子ディスプレ イの可能性を示唆する研究の流れについて紹介した い. 
まず，リガンドスクリーニング系について述べ る。これまで，酵母細胞を宿主とするレポーターを 用いた各種アッセイ系として, 栄養要求性遺伝子と 選択培地を用いた増殖による選別や， $\beta$-ガラクトシ ダーゼなど酵素活性による解析などが利用されてい る。これらの方法は現在でも汎用されており，特別 な実験機器類を用いないでアッセイができるという 利点がある一方，増殖選別では細胞の生育に時間を 要し，酵素活性による解析では測定毎に基質を添加 する必要があるなど，一度に多数のアッセイが必要 な場合には限界がある。そこで，より簡便で定量的 な評価が行えるシステムとして，蛍光タンパク質の 発現をレポーターとしたヒト GPCR（G-protein coupled receptor）の酵母細胞膜へのディスプレイ と，その細胞を用いたアッセイ系が開発されている (Fig. 4). ${ }^{16)}$ モデルとして，ヒトソマトスタチンレ セプター（SSTR5）を酵母細胞膜上にディスプレ イするにあたり，酵母の内在性 GPCR が破壞され,

SSTR5 をディスプレイするための遺伝子が導入さ れた。これにより，内在性 GPCR の競合発現が抑 制されると期待でき，GFPレポーターを含む SSTR5 ディスプレイ酵母株に，SSTR5 のリガンド 分子であるソマトスタチン（S-14）を添加し，蛍光 強度がフローサイトメーターにより計測された。そ の結果，S-14 の添加に応答してレポーターの GFP による蛍光を検出するに至っており，細胞膜上にデ

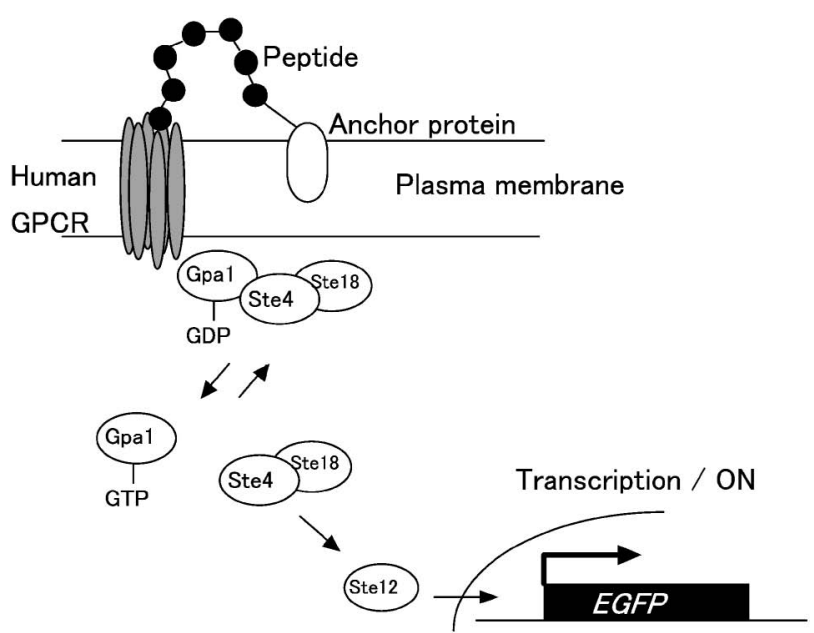

Fig. 4. Molecular Display of Human GPCR on Yeast Plasma Membrane

Ligand-candidates (peptides) can be displayed on the same surface using anchor protein. The expression of EGFP is activated via MAPK-signa transduction when a ligand stimulates a GPCR in this system.
イスプレイした SSTR5 から G タンパク質を介して シグナルが伝達されたと理解できる。 さらにリガン ドのペプチドは, Fig. 4 のようにアンカータンパク 質と融合し，ライブラリー化が可能であることも明 らかとなっている。 このように，ヒトレセプターの アッセイ系として，酵母細胞膜にディスプレイした レセプターの機能を, 細胞内蛍光シグナルの発現量 により迅速，かつ定量的に評価できることが明らか となり，本システムにより医薬候補化合物分子とな るリガンドのスクリーニングに展開できると期待さ れる。

次に, 細胞質側への分子ディスプレイ系について 述べる，前項での細胞壁アンカーによる分子ディス プレイ，本項目で述べたディスプレイ系のいずれに おいても，目的分子を細胞の外側に固定し，提示す る技術であったが，細胞質側に固定することも可能 で，これにより目的分子と細胞質に存在するタンパ ク質，あるいは発現量や時期をコントロールした夕 ンパク質との相互作用が検出できる。ここでは,

Snc2 タンパク質の細胞膜ターゲティングドメイン （MTD; membrane-targeting domain）による Z ド メインの固定化と，細胞質に発現させた Fc の相互 作用を FRET (Fluorescent resonance energy trans-

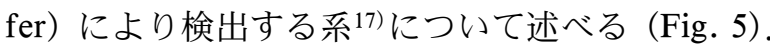

Snp2 は Synaptobrevin のホモログで，標的分子の 膜輸送を仲介しており，この $\mathrm{C}$ 末側領域の膜貫通 ドメイン (CTM; C-terminal transmembrane domain) が，Zドメインの固定化部位として利用できる。 た， Z ドメインならびに Fc に融合する蛍光タンパ ク質としては，FRET を引き起こし得る蛍光特性を 有する様々な分子の組合わせが考えられるが，ここ では ECFP（Enhanced cyan fluorescent protein）と EYFP (Enhanced yellow fluorescent protein) が選 択された。 Z ドメインならびに Fc に融合したタン パク質が酵母細胞内で共発現され，FRET 現象につ いて検討が行われた。コントロールとして， ECFP-Z 融合タンパク質を細胞質内で発現させた場 合は，ECFP の励起光 $(440 \mathrm{~nm})$ では，ECFP から の蛍光シグナルしか検出されなかったが, ECFP-Z 融合タンパク質をMTD により細胞膜に固定化した 場合では，ECFP の励起光により EYFP の蛍光 $(535 \mathrm{~nm})$ ，すなわち FRET シグナルが検出でき た。ここで MTD として，他の細胞膜局在タンパク 


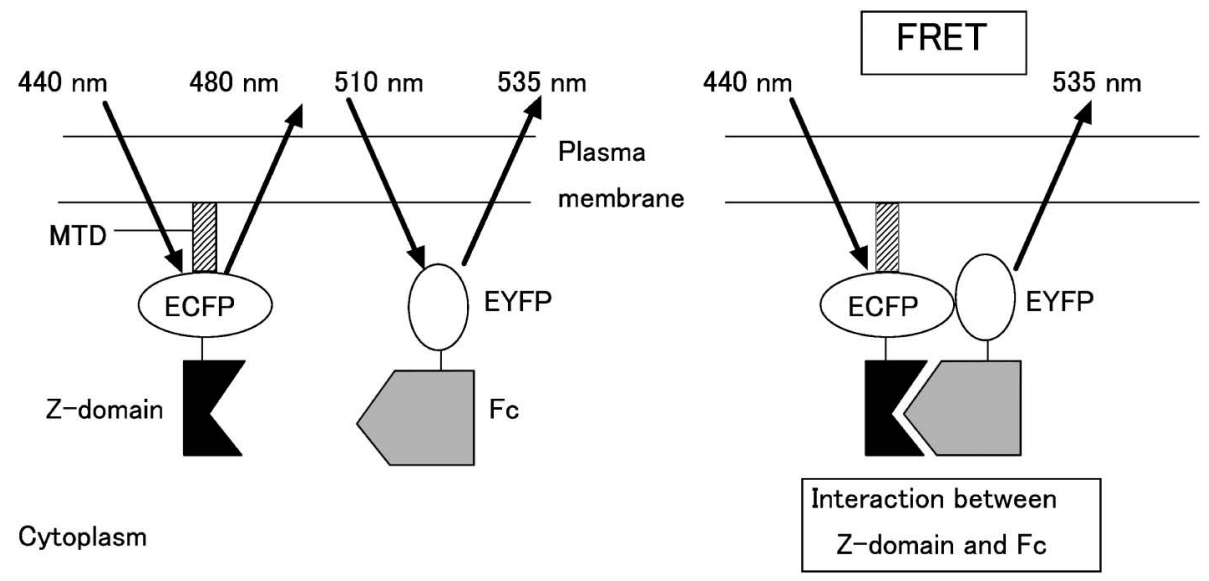

Fig. 5. Immobilization of Proteins in Cytoplasmic Face to Observe Protein-protein Interactions by FRET

質として Ras2 タンパク質のものも利用が検討され ているが，酵母での FRET によるタンパク質相互 作用検出系においては Snc2 の方が FRET 効率がよ いことも確認されている．また，本手法の細胞内に おけるタンパク質相互作用検出系としての利点は, 蛍光顕微鏡により可視化できることに加え，一方を 細胞膜に局在化させることにより，細胞質全体に発 現させて結果的に相互作用を観察したい両者を拡散 させてしまう場合と比較すると，検出効率がよいと いうことも挙げられる.

\section{6. おわりに}

以上，分子ディスプレイの背景，酵母分子ディス プレイの原理と概要，並びにその応用例として創薬 基盤技術の可能性を秘める要素技術の一部を概説し た。本技術により創製された細胞は「アーミング酵 母（Arming yeast）」として C\&E News で紹介さ れ18)て以来，様々な報文においても同名称が使用さ れ，多くの研究者の注目を集めて今日に至ってい る. また，分子ディスプレイにより「アーミング」 した酵母自身がワクチンとなり，医薬としての可能 性を有していることを示す論文が既に報告され始め ている. ${ }^{19)}$ 経ロワクチンとしてヒトに適用する場合 は，遺伝子組換えの問題をクリアする必要があるが, non-GMO という新しいスタイルの分子ディスプレ イ法が開発されており, ${ }^{20)}$ インフルエンザを始めと する各種感染症予防ワクチンとしての活用も十分に 考えられる，今後，様々なスクリーニング技術 （ハード）の活用により，本手法により創製された 分子や細胞が創薬研究の進展に貢献するものと期待 できる. 謝辞＼cjkstart本稿で紹介した分子ディスプレイの応用 例は，筆者の前研究室に在籍した卒研生諸氏，なら びに共同研究者である神戸大学大学院の近藤昭彦教 授との共同研究による成果であり，分子ディスプレ 个技術の開発者である京都大学大学院農学研究科植 田充美教授と同グループによる共同研究の成果もあ わせて, 総説としてまとめさせて頂いたことを深く 感謝申し上げます。

\section{REFERENCES}

1) Shibasaki S., Maeda H., Ueda M., Anal. Sci., 25, 41-49 (2009).

2) Smith G. P., Science, 228, 1315-1317 (1985).

3) Nord K., Gunneriusson E., Ringdahl J., Ståhl S., Uhlén M., Nygren P. A., Nat. Biotechnol., 15, 772-777 (1997).

4) Hofnung M., Methods Cell Biol., 34, 77-105 (1991).

5) Stathopoulos C., Georgiou G., Earhart C. F., Appl. Microbiol. Biotechnol., 45, 112-119 (1996).

6) Maassen C. B., Laman J. D., den BakGlashouwer M. J., Tielen F. J., van HoltenNeelen J. C., Hoogteijling L., Antonissen C., Leer R. J., Pouwels P. H., Boersma W. J., Shaw D. M., Vaccine, 17, 2117-2128 (1999).

7) Shibasaki S., Ueda M., Recent Pat. Biotechnol., 3, 19-27 (2009).

8) Shibasaki S., Ueda M., Ye K., Shimizu K., Kamasawa N., Osumi M., Tanaka A., Appl. Microbiol. Biotechnol., 57, 528-533 (2001).

9) Shibasaki S., Ninomiya Y., Ueda M., Iwa- 
hashi M., Katsuragi T., Tani Y., Harashima S., Tanaka A., Appl. Microbiol. Biotechnol., 57, 702-707 (2001).

10) Ueda M., Tanaka A., Biotechnol. Adv., 18, 121-140 (2000).

11) Kuroda K., Shibasaki S., Ueda M., Tanaka A., Appl. Microbiol. Biotechnol., 57, 697-701 (2001).

12) Ito J., Sahara H., Kaya M., Hata Y., Shibasaki S., Kawata K., Ishida S., Ogino C., Fukuda H., Kondo A., J. Mol. Catal. B: Enzym., 55, 69-75 (2008).

13) Shibasaki S., Kawabata A., Ishii J., Yagi S., Kadonosono T., Kato M., Fukuda N., Kondo A., Ueda M., Appl. Microbiol. Biotechnol., 75, 821-828 (2007).

14) Shibasaki S., Ueda M., Iizuka T., Hirayama M., Ikeda Y., Kamasawa N., Osumi M., Tanaka A., Appl. Microbiol. Biotechnol., 55,
471-475 (2001).

15) Fukuda N., Ishii J., Shibasaki S., Ueda M., Fukuda H., Kondo A., Appl Microbiol. Biotechnol., 76, 151-158 (2007).

16) Ishii J., Matsumura S., Kimura K., Tatematsu K., Kuroda S., Fukuda H., Kondo A., Biotechnol. Prog., 22, 954 (2006).

17) Shibasaki S., Kuroda K., Nguyen H. D. Mori T., Zou W., Ueda M., Appl. Microbiol. Biotechnol., 70, 451-457 (2006).

18) Anonymous, Chem. Eng. News, 75, 32 (1997).

19) Tamaru Y., Ohtsuka M., Kato K., Manabe S., Kuroda K., Sanada M., Ueda M., Biotechnol. Prog., 22, 949-953 (2006).

20) Miura N., Aoki W., Tokumoto N., Kuroda K., Ueda M., Appl. Microbiol. Biotechnol., 82, 293-301 (2009). 